\title{
Leaf Abscisic Acid Accumulation in Response To Substrate Water Content: Linking Leaf Gas Exchange Regulation with Leaf Abscisic Acid Concentration
}

\author{
William L. Bauerle', William W. Inman, and Jerry B. Dudley² \\ Department of Horticulture, Clemson University, Clemson, SC 29634-0319
}

\begin{abstract}
AdDitional INDEX wORDs. stomatal conductance, drought tolerance, genotype variation
Abstract. Quantitative differences in leaf abscisic acid ( $\left.\mathrm{AB} \mathrm{A}_{\mathrm{L}}\right)$ among four cultivars of red maple (Acer rubrum $\mathrm{L}$.) and one freeman maple (Acer $\times$ freemanii E. Murray) cultivar were investigated. This study tested the hypothesis that $\mathrm{ABA}_{\mathrm{L}}$ concentration can be used to compare the effects of water stress on the gas exchange response of five different maple genotypes, including four red maple cultivars ['Summer Red', 'October Glory', 'Autumn Flame', and 'Franksred' ('Red Sunset')] and one hybridized freeman maple cultivar ['Jeffersred' ('Autumn Blaze')]. Two-year-old cloned genotypes of red maple and freeman maple were subjected to two treatments: irrigated daily to container capacity or irrigation withheld for one drought and recovery cycle. Leaf abscisic acid concentration, gas exchange, and wholetree sap flow measurements were conducted under well-watered and drought stress conditions. Over the course of the drought stress and recovery phase, net photosynthesis $\left(A_{n e t}\right)$, stomatal conductance $\left(g_{s}\right)$, and transpiration $(E)$ declined as $\mathrm{ABA}_{\mathrm{L}}$ and instantaneous water use efficiency $\left(\mathrm{A} / \mathrm{g}_{\mathrm{s}}\right)$ increased. Until severe water stress conditions were prominent, water use was higher in 'Summer Red' as compared to 'October Glory'. This study found that $\mathrm{ABA}_{\mathrm{L}}$ tracked $\mathrm{g}_{\mathrm{s}}$ and that stomatal responsiveness to substrate moisture deficit is likely mediated by $A B A$ accumulation in leaf tissue. This research demonstrates a leaf level physiological response to substrate volumetric water content that appears to depend on $A B A_{L}$ concentration. In addition, the evidence in this study indicates that $A B A_{L}$ may be used as a potential surrogate for the $\mathrm{g}_{\mathrm{s}}$ response to substrate water stress and could become part of a cultivar drought tolerance selection strategy for red maple and freeman maple.
\end{abstract}

Red maple and freeman maple are popular ornamental shade trees. Due to the aesthetic characteristics, genotypes of these maples are among the most commonly planted street trees. The suite of abiotic stresses in metropolitan areas, particularly drought, underscores the need to improve the stress tolerance of shade trees under a wide range of environmental situations. There is considerable evidence to suggest that stomatal conductance $\left(\mathrm{g}_{\mathrm{s}}\right)$ may be regulated by chemical signals in ecotypes of red maple (Bauerle et al., 2003a, 2004a). The short-term response to chemical signals could mediate $g_{s}$, and the regulation of $g_{s}$ over the long-term could occur by a gradual change in concentration that remained reasonably constant as the soil became progressively drier (Whitehead, 1998). This observation reveals that a cultivar selection strategy, based on the concentration of chemical signals in leaf tissue, may facilitate selection of plants suited to tolerate water stress.

Evaluation of genetic variability in drought tolerance requires a framework of analysis that allows for genetic differences in stomatal control [e.g., abscisic acid (ABA) concentration in comparison to $\mathrm{g}_{\mathrm{s}}$ at a given soil water status] to be distinguished from developmental differences (e.g., the effect of leaf area on the rate of soil water depletion) (Borel et al., 1997). Abscisic acid is generally considered a root-sourced hormone that moves from the roots to the shoots in the transpiration stream. Recently,

Received for publication 23 Aug. 2005. Accepted for publication 21 Nov. 2005. We thank E. Poulin for earlier reviews of this manuscript and F. Vermeylen and L. Grimes for statistical discussions. The State of South Carolina Research and Experiment Station funded this research.

1Corresponding author: e-mail: bauerle@clemson.edu

${ }_{2}^{2}$ Present address: North Carolina State Univ., Cooperative Extension, Wilmington, NC 28403.
Freundl et al. (1998) found indications that interspecific differences in the relative importance of soil-sourced chemical signals should be expected in the root-to-shoot signaling process. The study identified the possibility that variation in drought tolerance may not only be under genetic control, but may manifest itself in plant characters such as leaf $\mathrm{ABA}\left(\mathrm{ABA}_{\mathrm{L}}\right)$ concentration and $\mathrm{g}_{\mathrm{s}}$. We have previously demonstrated a red maple stomatal closure response to $\mathrm{ABA}_{\mathrm{L}}$ in wild-type red maple (Bauerle et al., 2003a, 2004a).

If genotype variation in $\mathrm{ABA}_{\mathrm{L}}$ accumulation exists, it is necessary to examine leaf responses to $\mathrm{ABA}$ by trying to understand the basis of any apparent differences in the sensitivity of the response at the site of ABA action (leaf stomata), which is also the link between the plant and the atmosphere (Bauerle et al., 2004b). An established method to clarify the role of ABA accumulation is the evaluation of genetic stocks potentially differing in their capacity to endogenously accumulate ABA (Alves and Setter, 2000; Read et al., 1991; Sanguineti et al., 1996). Recently, Landi et al. (2001) demonstrated that selection for low bulk $\mathrm{ABA}_{\mathrm{L}}$ concentration led to populations with superior agronomic performance in two corn (Zea mays L.) populations. Conversely, we hypothesize that for managed landscape survival purposes, selection for drought tolerance may be a strategy for identifying cultivars that could be used in xeric environments.

In a prior study, we imposed a severe drought treatment to different wild ecotypes of red maple (Bauerle et al., 2003a). Results from the ecotype study indicate that red maple populations from wet-site habitats produce higher levels of $\mathrm{ABA}_{\mathrm{L}}$ in response to water stress than populations common to dry-sites. Furthermore, the $\mathrm{ABA}_{\mathrm{L}}$ tracked $\mathrm{g}_{\mathrm{s}}$, where higher $\mathrm{ABA}_{\mathrm{L}}$ was associated with lower $g_{s}$ values. These results suggest that wild-type red maple ecotypes have evolved highly regulated ABA synthesis and 
degradation controls for drought stress management. In a subsequent cultivar study, we found photosynthesis, water use, and light absorption to vary among red and freeman maple cultivars (Bauerle et al., 2003b). Taken together, the two studies provided the impetus to investigate $\mathrm{ABA}_{\mathrm{L}}$ variability among commercially available genotypes of red maple and freeman maple in order to potentially elucidate drought stress tolerance. The objectives of this study were 1) to compare genotype performance under low substrate moisture conditions for selection of drought tolerance that could enhance survival in managed landscapes, and 2) to address the linkage between $\mathrm{ABA}_{\mathrm{L}}$ concentration, changing substrate water status and leaf gas exchange to determine whether $\mathrm{ABA}_{\mathrm{L}}$ can be used as a surrogate for selection of plants suited to xeric conditions.

\section{Materials and Methods}

Plant material. Four South Carolina-grown (Parsons Nursery, Georgetown, S.C.) red maple cultivars ['October Glory', 'Franksred' ('Red Sunset'), 'Summer Red', and 'Autumn Flame'] and one freeman maple cultivar ['Jeffersred' ('Autumn Blaze')] were transplanted into 56.7-L Spin Out (Nursery Supplies, Chambersburg, Pa.) treated plastic pots containing a mixture of 20 pine bark : 1 sand (v/v), fertilized with $8.3 \mathrm{~kg} \cdot \mathrm{m}^{-3}$ of $20 \mathrm{~N}-3.0 \mathrm{P}-8.3 \mathrm{~K}$ Nutricote (type 360; Chisso-Asahi Fertilizer Co., Tokyo), and shipped to Clemson Univ. The plants were spaced $1.5 \mathrm{~m}$ centerto-center at the Calhoun Field Laboratory (Clemson, S.C.) and irrigated four times daily to container capacity with pressure compensating spray stakes (ML Irrigation, Laurens, S.C.). The 1.5-m-tall cultivars were the same age and size. For each cultivar, treatments consisted of a well-watered control $(n=6)$ and a drought treatment where water was withheld $(n=6)$. Randomly selected plants fromeach source and treatment combination were chosen for repeated sampling of gas exchange, sap flow, substrate moisture, and $\mathrm{ABA}_{\mathrm{L}}(\mathrm{n}=6)$. To eliminate evaporation from the substrate surface and/or water penetration in case of rain, white plastic bags were cut and sealed to the stem with Parafilm (American National Can, Greenwich, Conn.). The bottom ends of the bags were left open for air circulation and secured to the pots with an elastic ring. The exterior of each container was wrapped with aluminum foil to reduce the container radiation load. For each genotype, treatments consisted of a well-watered control $(n=6)$ watered four times daily and a drought treatment where water was withheld $(n=6)$ until reaching a volumetric water content of $9 \%$ (a leaf water potential of approximately -2 MPa under full sun solar noon conditions, see below and Fig. 1).

WATER MEASUREMENTS. In order to relate substrate moisture to plant water status, we paired a sub-sample of full sun solar noon leaf water potential $\left(\Psi_{\mathrm{L}}\right)$ measured with a pressure chamber (Plant Moisture Status Console; Soil Moisture Equipment Corp., Santa Barbara, Calif.) to bulk moisture content of the substrate. For water potential readings, leaves were selected on the crown's south side and covered with aluminum foil $24 \mathrm{~h}$ prior to the reading. At solar noon, a leaf was removed and, while still covered with foil, its water potential measured in parallel with soil moisture. This measurement provided an estimate of the xylem stream water potential. We followed the protocol of Fulton et al. (2001) for equilibration of $\Psi_{\mathrm{L}}$ under solar noon field conditions. Figure 1 illustrates the linear relationship between $\Psi_{\mathrm{L}}$ under full sun solar noon conditions and substrate volumetric water content. Bulk volumetric water content of $9 \%$ was approximately equivalent to a solar noon $\Psi_{\mathrm{L}}$ of $-2 \mathrm{MPa}$ and thus, provided us with a non-

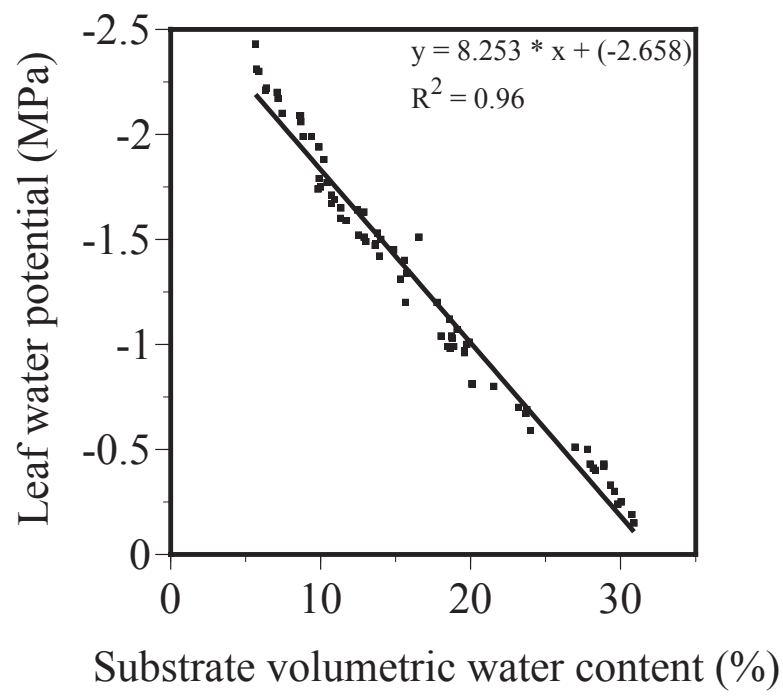

Fig. 1. The relationship between leaf water potential (MPa) measured under full sun conditions at solar noon vs. substrate volumetric water content (\%). Four red maple cultivars ['October Glory', 'Franksred' ('Red Sunset'), 'Summer Red', and 'Autumn Flame'] and one freeman maple cultivar ['Jeffersred' ('Autumn Blaze')] were randomly sampled to develop the relationship.

destructive rapid means to assess plant water status (Fulton et al., 2001; Shackel et al., 2001). In addition, the reflective aluminum foil leaf cover ensured that equilibrium was reached between the nontranspiring leaf and the stem, thus eliminating the potential influence of friction from the water conduction pathway (Bauerle et al., 1999). Using bulk volumetric water content allowed us to repeatedly and rapidly monitor substrate water status and infer plant water status without sacrificing transpiring leaves (Fig. 1).

Initially, all plants were kept well watered and then watered to saturation and allowed to drain for $18 \mathrm{~h}$ prior to the study. After drainage and thereafter, bulk volumetric water content of each container was measured in four locations with a Theta Probe (type ML2; Delta-T Devices, Cambridge, England) at 10 and $20 \mathrm{~cm}$ below the substrate surface and pooled for a container average. Readings were taken in predrilled locations on opposite sides of the pot. Drilled holes were large enough to allow the probe adequate movement and contact with the substrate surface within the container. Although volumetric water contents were slightly higher in the lower container level, a linear relationship between the average upper and lower substrate level allowed us to average the readings to estimate bulk volumetric water content for each container (Fig. 2). Furthermore, at the drought treatment threshold bulk volumetric water content of $9 \%$, very little variation in container substrate volumetric water content was observed between the upper and lower measurement location (Fig. 2).

To minimize variation within the drought stress episode, the volumetric water content of each plant was assessed individually. When the substrate of an individual replicate of a given genotype reached a bulk volumetric water content of $9 \%$, a timed drought and recovery cycle was initiated. During this cycle, leaves were sampled on days $1,3,5,6,7$, and 9. Plants were rewatered to container capacity the evening of the fifth day and tracked for recovery responses for $4 \mathrm{~d}$ of poststress observations. When a plant completed its cycle, it was removed from the study.

LEAF GAS EXCHANGE. Randomly selected plants from each source and treatment combination were chosen for repeated sampling of gas exchange $(n=6)$. Prior to arrival at a moisture 


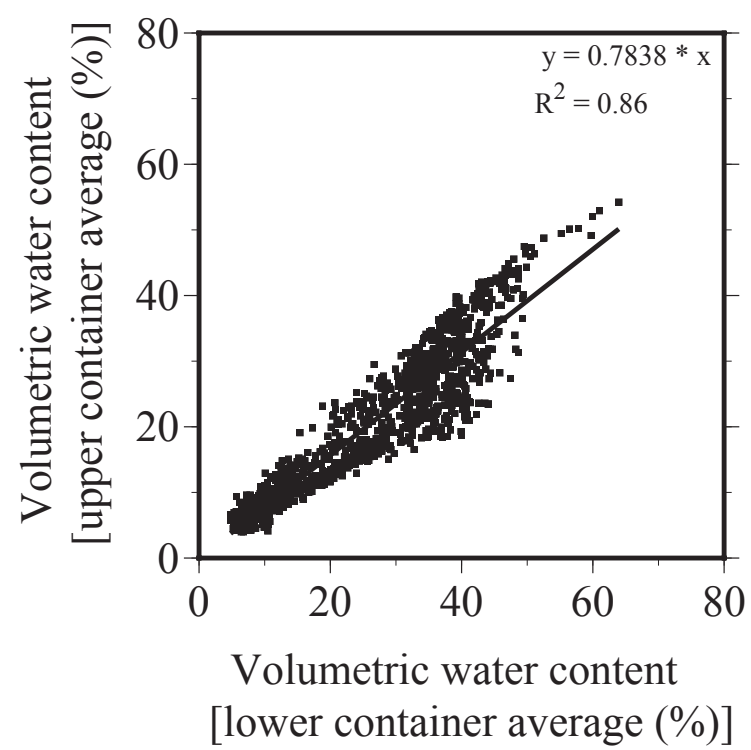

Fig. 2. The relationship between volumetric water content (\%) measured on two opposite sides of the container at $10 \mathrm{~cm}$ from the substrate surface (upper container average) and on two opposite sides of the container at $20 \mathrm{~cm}$ from the substrate surface (lower container average). Four red maple cultivars ['October Glory', 'Franksred' ('Red Sunset'), 'Summer Red', and 'Autumn Flame'] and one freeman maple cultivar ['Jeffersred' ('Autumn Blaze')] were randomly sampled to develop the relationship.

status of $9 \%$, plants were measured every $2 \mathrm{~d}$, and during the drought and recovery cycle, plants were measured at the same time as soil moisture status. Net photosynthesis $\left(\mathrm{A}_{\mathrm{net}}\right)$ and $\mathrm{g}_{\mathrm{s}}$ were measured on the first fully expanded leaf in full sun using a portable steady state gas-exchange system (CIRAS-I; PP Systems, Haverhill, Mass.) equipped with a light and temperature controlled cuvette [model PLC5 (B); PP Systems]. On the terminal tip, measurements were taken on the youngest fully expanded leaf from 0900 to $1230 \mathrm{HR}$. The leaves were tagged and on any given day, measurements were taken in random order to compensate for any effects caused by time of sampling. All leaves were south oriented and fully exposed to reduce environmental interactions. Leaf temperature within the cuvette was controlled at $25^{\circ} \mathrm{C}$, photosynthetic photon flux density $(P P F D)$ was maintained at $1000 \mu \mathrm{mol} \cdot \mathrm{m}^{-2} \cdot \mathrm{s}^{-1}$ with the cuvette light source, and vapor pressure deficit in the cuvette kept at $1.3 \pm 0.4 \mathrm{kPa}$. Temperature set points were taken as those optimum for temperate-zone $\mathrm{C}_{3}$ species (Kozlowski and Pallardy, 1997). Saturating PPFD set points were derived from Bauerle et al. (2003a). Measurements were recorded after reaching steady state.

ABA sampling. Leaf disks were collected four times during the experiment immediately after gas exchange measurements. Using a 1-cm (i.d.) cork borer, leaf disks were collected from the leaf opposite the gas exchange leaf (red maple - opposite leaf arrangement). The protocols were modifications of Alves and Setter (2000). Briefly, five 1-cm-diameter leaf disks were harvested from each replicated seedling and immediately placed in a precooled $(0$ $\left.{ }^{\circ} \mathrm{C}\right) 1.5$-mL microcentrifuge tube containing $650 \mu \mathrm{L}$ of extraction medium ( $80 \%$ v/v methanol, $20 \%$ v/v glass distilled $\left.\mathrm{H}_{2} \mathrm{O}\right)$. Samples were stored at $-18^{\circ} \mathrm{C}$ until analysis. A $200-\mu \mathrm{L}$ extract per sample was lyophilized and then redissolved in $150 \mu \mathrm{L}$ of aqueous $+1 \%$ $\mathrm{v} / \mathrm{v}$ glacial acetic acid with sonication. Chromatography columns were constructed with micropipette tips containing $0.15 \mathrm{~g}$ of silica $\mathrm{C}_{18}$ packing material (40 $\mu \mathrm{m}$ particle size). Columns were washed with $800 \mu \mathrm{L}$ of $95 \% \mathrm{EtOH}$ and then with $600 \mu \mathrm{L}$ of $20 \% \mathrm{MeOH}$
$+1 \% \mathrm{v} / \mathrm{v}$ glacial acetic acid with suction applied via a vacuum aspirator (model QIAvac 96; Qiagen, Valencia, Calif.). As soon as washing was complete, the extract was loaded under constant vacuum at a rate of $\approx 5 \mu \mathrm{L} \cdot \mathrm{s}^{-1}$. The column was then washed two times with $200 \mu \mathrm{L}$ of $20 \% \mathrm{MeOH}+1 \% \mathrm{v} / \mathrm{v}$ glacial acetic acid. Columns were then eluted with $200 \mu \mathrm{L}$ of $55 \% \mathrm{MeOH}$ and the ABA extract collected. Upon collection of elute, the samples were again stored at $-18{ }^{\circ} \mathrm{C}$.

ABA Assay. ABA was assayed by enzyme-linked immunosorbent assay (ELISA) as described by Alves and Setter (2000). Each well of a 96-well microtiter plate (Corning/Costar High Binding \#3366; Corning, Corning, N.Y.) was coated with $25 \mu \mathrm{L}$ of ABA-bovine serum albumin conjugate. After incubation, for $24 \mathrm{~h}$ at $5{ }^{\circ} \mathrm{C}$, the plate was decanted and washed four times with TBST [Tris-buffered saline with $0.02 \%$ v/v Tween-20 (Sigma, St. Louis)] with 5-min incubations per wash. One hundred microliters of TBSA (Tris-buffered saline + bovine serum albumin) and $10 \mu \mathrm{L}$ of eluted sample were added to each well. Then 100 $\mu \mathrm{L}$ of anti-ABA monoclonal antibody [clone $15-\mathrm{I}_{5} \mathrm{C}_{5}$ (currently available from Agdia, Elkhart, Ind.)] was added to each well. The plate was incubated for $24 \mathrm{~h}$ at $5{ }^{\circ} \mathrm{C}$. After incubation, the plate was again decanted and washed with TBST a total of four times. One hundred and eighty microliters of diluted secondary antibody [anti-mouse-alkaline phosphotase conjugate (A-3562; Sigma) in TBST with $0.1 \%$ (w/v) BSA] was added to each well. The plate was incubated at $5^{\circ} \mathrm{C}$ for $24 \mathrm{~h}$.

Once the final incubation was complete, the plate was decanted and again washed four times. Colorimetric reagent, containing para-nitrophenylphosphate, PNPP(N3129; Sigma) in diethanolamine buffer was added and the plate was left to develop for 1 $\mathrm{h}$ at room temperature. After $1 \mathrm{~h}$, the plate was read with a plate reader at a wavelength of $405 \mathrm{~nm}$ (model BS10000; Packard BioScience, Meriden, Conn.). (+) ABA content was determined by calculations based on (+) ABA calibration standards. A spreadsheet macro written in Excel (Microsoft Corp., Redmond, Wash.) provided a logit-transformed plot of the standard curve, calculated regressions, and predicted pmol ABA per well. Samples were replicated three times in the assay and averaged.

Measurements of SAP FLow. Commercially available sap flow gauges (Dynamax, Houston) were used for all measurements. The gauges have been described in detail by Steinberg et al. (1990). Details of the methodology used in sap flow set up and measurement in this study followed those of Bauerle et al. (2002). Specific to this study, gauges were evenly distributed (14 total) between two red maple cultivars ('Summer Red' and 'October Glory') in both the well-watered $(n=3)$ and drought-stressed ( $=4$ ) treatments. When the substrate of an individual replicate of a given genotype reached a bulk volumetric water content of $9 \%$, a timed drought and recovery cycle was initiated. Plants were rewatered to container capacity the evening of the fifth day and tracked for recovery responses. When a plant completed its cycle, it was removed from the study.

EXPERIMENTAL DESIGN AND DATA ANALYSIS. Treatments were applied in a completely random repeated measures design with a factorial arrangement between the two irrigation treatments (control and drought) and five genotypes. Red maple and freeman maple cloned genotypes were assigned randomly to treatments and placed on a gravel pad in a completely randomized design. There were six replications per treatment genotype combination. Data were analyzed using analysis of variance (SAS Institute, Cary, N.C.). Means of $A_{\text {net }}, g_{s}$, instantaneous water use efficiency $\left(A / g_{s}\right)$, calculated internal $\mathrm{CO}_{2}$ mole fraction in air $\left(\mathrm{C}_{\mathrm{i}}\right)$, transpiration 
(E), and $\mathrm{ABA}_{\mathrm{L}}$ concentrations were separated at each volumetric content by using Fisher's least significant difference (LSD) at $P=$ 0.05 . Sap flow data was analyzed by an alalysis of variance on the slopes of water loss versus volumetric water content and cultivars were compared with regression covariance analysis (SAS).

\section{Results}

Gas exchange and leaf ABA concentration. The means for $A_{\text {net }}, g_{s}, A / g_{s}, C_{i}, E$, and $A_{B A}$ of plants under well-watered container capacity conditions are reported in Table 1. A Fisher's LSD test at $P=0.05$ was used to compare well-watered genotypes over the entire study period because no significant differences were found among substrate volumetric water contents among genotypes; however, significant differences were found for each gas exchange parameter (Table 1). Mean leafE for 'Summer Red' was $\approx 11 \%$ higher than that of 'October Glory', a result that agrees with daily whole tree E losses under drought conditions (Fig. 3 ). With respect to the other gas exchange parameters measured under irrigated conditions, cultivars Red Sunset and Summer Red stood out as the most significantly different as compared to the other three. The difference was attributed to a higher $\mathrm{A}_{\text {net }}, \mathrm{g}_{\mathrm{s}}$, and $\mathrm{E}$ rate, offset by a lower $\mathrm{A} / \mathrm{g}_{\mathrm{s}}$. Under well-watered conditions, $\mathrm{ABA}_{\mathrm{L}}$ were very low in all cases and regardless of genotype, no differences were observed (Table 1).

Table 2 reflects the results of a Fisher's LSD test at $P \leq 0.05$ at four distinct volumetric water contents. The distinct periods are as follows: well-watered and prior to drought (A), initial threshold water deficit (B), $5 \mathrm{~d}$ (continuous) at threshold water deficit (C), and after $4 \mathrm{~d}$ (continuous) of irrigation (D, peak recovery phase). Withholding irrigation (phase $\mathrm{B}$ ) led to a rapid decline in volumetric water content ( $50 \%$ to $30 \%$ within a 24 -h period) and a decrease in $\mathrm{A}_{\text {net }}, \mathrm{g}_{\mathrm{s}}, \mathrm{C}_{\mathrm{i}} \mathrm{E}$, and $\mathrm{ABA}_{\mathrm{L}}$. The findings are similar to those obtained by Bauerle et al. (2003a) in a red maple ecotype drought stress study, but different in that the genotypes have higher gas exchange values than either wet or dry site wild red maple ecotypes. Although the volumetric water content decline had an overall negative effect on $\mathrm{A}_{\text {net }}, \mathrm{g}_{\mathrm{s}}, \mathrm{E}$, and $\mathrm{C}_{\mathrm{i}}$ (Tables 1 and 2 ), Table 2 part A shows that under well-watered conditions, volumetric water content was $>30 \%$ and all five genotypes were similar to each other for both gas exchange and $\mathrm{ABA}_{\mathrm{L}}$. However, upon reaching a volumetric water content of $<10 \%$ from transpirational substrate water extraction, only 'Red Sunset' $g_{s}$ was significantly lower than 'Autumn Flame' and 'October Glory', but E was lower than all cultivars. After $5 \mathrm{~d}$ of a consistently low volumetric water content of $<10 \%, \mathrm{E}, \mathrm{g}_{\mathrm{s}}$, and $\mathrm{A}_{\text {net }}$ did not show a significant difference among the genotypes, however, the $\mathrm{A} / \mathrm{g}_{\mathrm{s}}$ of 'Summer Red' approached from two to five times greater $\mathrm{A} / \mathrm{g}_{\mathrm{s}}$ than any other cultivar under study.

The $\mathrm{ABA}_{\mathrm{L}}$ concentrations illustrate that $\mathrm{ABA}_{\mathrm{L}}$ increased approximately seven fold between $24 \mathrm{~h}$ after irrigation termination and a substrate volumetric water content of $<10 \%$. After $5 \mathrm{~d}$ of consistently low $(<10 \%)$ volumetric water content (phase B), $\mathrm{ABA}_{\mathrm{L}}$ values rose to $\approx 9$-fold higher than levels before irrigation was withheld. After rewatering and daily irrigation to container capacity for four continuous days of postdrought recovery, data pooled across the genotypes showed that gas exchange recovered to $\approx 50 \%$ of prestress levels and $\mathrm{ABA}_{\mathrm{L}}$ dropped to less than half the level present immediately before the recovery phase (Table 2 phase $\mathrm{C}$ vs. D). Hydrophobic substrate characteristics of the pine-bark/sand substrate prevented volumetric water contents from reaching much $>30 \%$, thus not allowing measurement above that substrate level. In addition, upon drought relief, all genotypes appeared to recover to similar gas exchange and $\mathrm{ABA}_{\mathrm{L}}$ after $4 \mathrm{~d}$ of drought relief.

SAP FLOW. Protocols that minimized the impact of environmentally induced stem temperature differentials were implemented (Gutiérrez et al., 1994). In addition, the degree of similarity in gauge configuration, uniform nursery environment, even-aged stand of genotypes, and identical spacing added to the among genotype standardization of the environmental influence on sap flow. Analyses of the two gauges, operated in the absence of heat "blanks," did not indicate environmentally induced stem temperature gradients and discounted the possibility of environmental artifacts that may influence readings (data not shown). Since both concurrently operated blanks were similar in $\Delta \mathrm{T}$ values, an environmental correction factor was not justified.

Daily whole-tree transpiration was measured to indicate the onset of water deficit. Figure 3 illustrates daily sap flow calculated per unit leaf area in relation to volumetric water content in replicates of 'Summer Red' and 'October Glory'. Linear regression lines in Fig. 3 cross the axes at a point that is not significantly different from the axes origin, so linear regression lines were forced through zero for analysis. The slopes were significantly different $(P<0.001)$ between the two cultivars, indicating that as volumetric water content declines, 'Summer Red' maintains a higher rate of water loss as compared to 'October Glory' (Fig. 1). Moreover, daily water use was $\approx 18 \%$ higher for 'Summer Red' $\left(3.5 \pm 0.18 \mathrm{~kg} \cdot \mathrm{m}^{2} \cdot \mathrm{d}^{-1}\right)$ as compared to 'October Glory' $(2.9 \pm 0.13$ $\left.\mathrm{kg} \cdot \mathrm{m}^{2} \cdot \mathrm{d}^{-1}\right)$ in the mean of three replicates per genotype kept under irrigated conditions (data not shown). Once severe water stress was reached ( $<10 \%$ volumetric water content) both genotypes had low daily E and leaf level E values were not significantly different (Table 2).

Table 1. Volumetric water content $(\mathrm{V})$, net $\mathrm{CO}_{2}$ assimilation $\left(\mathrm{A}_{\mathrm{net}}\right)$, stomatal conductance $\left(\mathrm{g}_{\mathrm{s}}\right)$, instantaneous water use efficiency $\left(\mathrm{A}_{\text {net }} / \mathrm{g}_{\mathrm{s}}\right)$, calculated internal $\mathrm{CO}_{2}\left(\mathrm{C}_{\mathrm{i}}\right)$, transpiration $(\mathrm{E})$, and leaf abscisic acid concentration $\left(\mathrm{ABA}_{\mathrm{L}}\right)$ of irrigated plants of four red maple and one freeman maple genotype. Results are given as means \pm SE of six replicates per treatment of the pooled data of four repeated measures over the course of the study due to nonsignificant differences in volumetric water content. Means followed by a superscript(s) are significantly different from the means of indicated genotypes(s). ${ }^{z}$

\begin{tabular}{|c|c|c|c|c|c|c|c|}
\hline Cultivar & V (\%) & $\begin{array}{c}\mathrm{A}_{\text {net }} \\
{\left[\mathrm{CO}_{2}\left(\mu \mathrm{mol} \cdot \mathrm{m}^{-2} \cdot \mathrm{s}^{-1}\right)\right]}\end{array}$ & $\begin{array}{c}\mathrm{g}_{\mathrm{s}} \\
{\left[\mathrm{H}_{2} \mathrm{O}\left(\mathrm{mol} \cdot \mathrm{m}^{-2} \cdot \mathrm{s}^{-1}\right)\right]}\end{array}$ & $\begin{array}{c}\mathrm{A}_{\mathrm{net}} / \mathrm{g}_{\mathrm{s}} \\
{\left[\mathrm{CO}_{2}\left(\mu \mathrm{mol} \cdot \mathrm{mol}^{-1} \mathrm{H}_{2} \mathrm{O}\right)\right]}\end{array}$ & $\begin{array}{c}\mathrm{C}_{\mathrm{i}} \\
\left(\mu \mathrm{mol} \cdot \mathrm{mol}^{-1}\right)\end{array}$ & $\begin{array}{c}\mathrm{E} \\
\left(\mathrm{mmol} \cdot \mathrm{m}^{-2} \cdot \mathrm{s}^{-1}\right)\end{array}$ & $\begin{array}{c}\mathrm{ABA}_{\mathrm{L}} \\
\left(\mathrm{pmol} \cdot \mathrm{cm}^{-2}\right)\end{array}$ \\
\hline$\overline{\text { Autumn Blaze }}$ & $>50$ & $16.7 \pm 0.6^{\mathrm{RS}}$ & $0.247 \pm 0.012^{\mathrm{RS}}$ & $69.35 \pm 2.36^{\mathrm{OG}}$ & $211 \pm 4.25^{\mathrm{OG}}$ & $3.35 \pm 0.12^{\mathrm{RS}}$ & $1.01 \pm 0.37$ \\
\hline Autumn Flame & $>50$ & $16.4 \pm 0.8 \mathrm{OG}, \mathrm{RS}, \mathrm{SR}$ & $0.231 \pm 0.012^{\mathrm{RS}, \mathrm{SR}}$ & $74.66 \pm 3.45^{\mathrm{RS}}$ & $203 \pm 5.50^{\mathrm{RS}}$ & $3.08 \pm 0.13^{\mathrm{RS}, \mathrm{SR}}$ & $1.31 \pm 0.52$ \\
\hline October Glory & $>50$ & $18.0 \pm 0.7^{\mathrm{AF}, \mathrm{RS}}$ & $0.230 \pm 0.013^{\mathrm{RS}, \mathrm{SR}}$ & $81.09 \pm 2.88^{\mathrm{AB}, \mathrm{RS}, \mathrm{SR}}$ & $198 \pm 4.77 \mathrm{AB}, \mathrm{RS}$ & $3.12 \pm 0.16^{\mathrm{RS}, \mathrm{SR}}$ & $1.11 \pm 0.41$ \\
\hline Red Sunset & $>50$ & $20.3 \pm 0.6^{\text {All }}$ & $0.336 \pm 0.019^{\mathrm{All}}$ & $63.36 \pm 2.79 \mathrm{AF}, \mathrm{OG}$ & $214 \pm 4.48^{\mathrm{AF}, \mathrm{OG}}$ & $4.10 \pm 0.17^{\mathrm{All}}$ & $1.92 \pm 0.34$ \\
\hline Summer Red & $>50$ & $18.0 \pm 0.7 \mathrm{AF}, \mathrm{RS}$ & $0.270 \pm 0.015^{\mathrm{AF}, \mathrm{OG}, \mathrm{RS}}$ & $69.41 \pm 3.17 \mathrm{OG}$ & $209 \pm 5.33^{\mathrm{AF}, \mathrm{OG}, \mathrm{RS}}$ & $3.47 \pm 0.14 \mathrm{AF}, \mathrm{OG}, \mathrm{RS}$ & $1.27 \pm 0.46$ \\
\hline
\end{tabular}

${ }^{7}$ 'Autumn Blaze' = AB, 'Autumn Flame' = AF, 'October Glory' = OG, 'Red Sunset' = RS, 'Summer Red' = SR, and All = different from other four genotypes. Statistical significance of differences among genotypes are given as $P \leq 0.05$. 


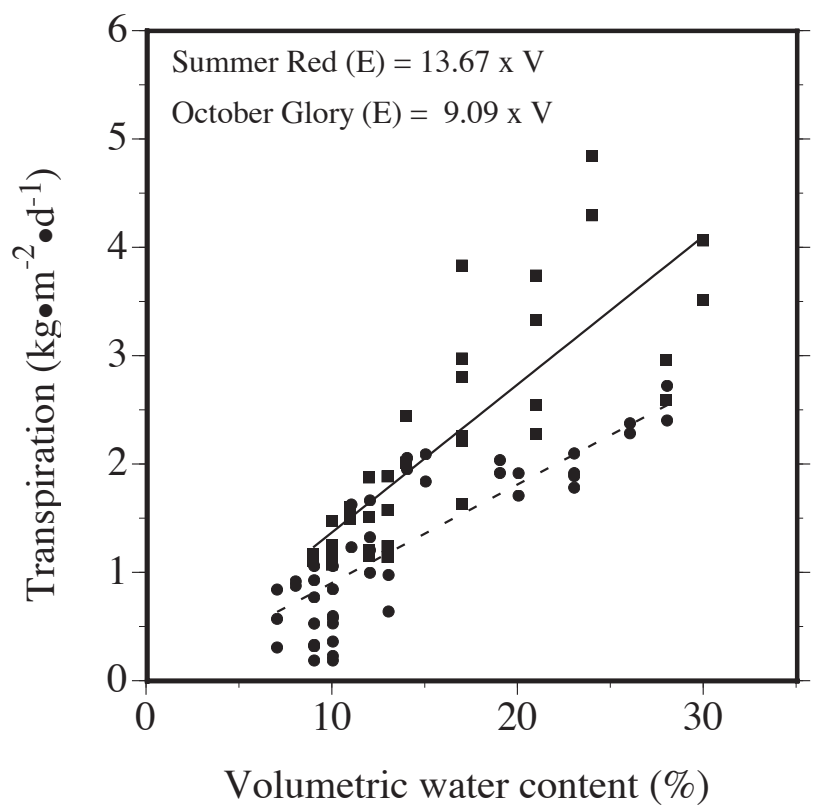

Fig. 3. Mean $(n=4)$ substrate volumetric water content [V $(\%)]$ vs. mean $(n=4)$ daily whole tree transpiration $\left(\mathrm{kg} \cdot \mathrm{m}^{-2} \cdot \mathrm{d}^{-1}\right)$ of 'SummerRed'(ם) vs. 'OctoberGlory' (-) red maple. Linear regression equations depict the predicted transpiration $(\mathrm{E})$ of water loss per genotype in $\mathrm{kg} \cdot \mathrm{m}^{-2} \cdot \mathrm{d}^{-1}$ upon multiplication by $\mathrm{V}$.

\section{Discussion}

The concentration of ABA in plant tissue is known to be affected by drought (Davies and Zhang, 1991; Jackson, 1993; Quarrie, 1991; Zeevaart and Creelman, 1988). Prior studies have shown that substrate drying can increase ABA concentrations in the bulk-leaf tissue several times above their normal endogenous values and may signal stomatal closure in response to substrate moisture (Bauerle et al., 2003a; Tardieu et al., 1992). In red maple genotypes, we too observed an increase in $\mathrm{ABA}_{\mathrm{L}}$ and a decline in $g_{s}$ in response to substrate water depletion. Results were similar to Zhang et al. (2001), where $\mathrm{ABA}_{\mathrm{L}}$ concentrations were quantitatively related to leaf conductance. According to Zhang et al. (2001), this indicates that ABA is involved in both gross stomatal closure in response to water stress and in fine-tuning stomatal aperture in response to an environment's water supply and/or demand. Although we developed a relationship between substrate volumetric water content and midday plant water status in order to compare genotype $\mathrm{ABA}_{\mathrm{L}}$ at specific volumetric water contents and/or plant water status (Fig. 1), the rate of ABA catabolism within the leaf and the rate of $\mathrm{ABA}$ re-exportation could have played a role in the total $\mathrm{ABA}_{\mathrm{L}}$ concentration (Wilkinson and Davies, 2002). Despite our inability to pinpoint the causal mechanism responsible for the variation among genotype $A B A$ concentrations inside the leaves, we did observe that as $\mathrm{ABA}_{\mathrm{L}}$ increased and $\mathrm{g}_{\mathrm{s}}$ declined, variation among maple genotypes was evident under stressful midday conditions. For instance, after arriving at the initial volumetric water content of $<10 \%$, 'Autumn Flame', the cultivar with the highest mean $g_{s}$ at the onset of drought, also had the lowest and most significantly different $\mathrm{ABA}_{\mathrm{L}}$ as compared to the other four genotypes. Although the differences could at least in part be related to differences in the rate of ABA synthesis and/or catabolism (Pekic et al., 1995), the results also suggest that genotype $\mathrm{ABA}_{\mathrm{L}}$ variation might be used as a selection criterion to select for genotypes with particular $\mathrm{g}_{\mathrm{s}}$ levels at specific levels of water stress.

Although ABA synthesis work is not new (for a review of

Table 2. Volumetric water content $(\mathrm{V})$, net photosynthesis $\left(\mathrm{A}_{\mathrm{net}}\right)$, stomatal conductance $\left(\mathrm{g}_{\mathrm{s}}\right)$, instantaneous water use efficiency $\left(\mathrm{A}_{\text {net }} / \mathrm{g}_{\mathrm{s}}\right)$, calculated internal $\mathrm{CO}_{2}\left(\mathrm{C}_{\mathrm{i}}\right)$, transpiration $(\mathrm{E})$, and leaf abscisic acid concentration $\left(\mathrm{ABA}_{\mathrm{L}}\right)$ of nonirrigated plants of four red and one freeman maple genotypes. Substrate volumetric water content was used to determine the drought cycle. Results are given as means \pm SE of six replicates per treatment per volumetric level. Means followed by a superscript(s) are significantly different from the means of indicated genotype(s). ${ }^{\mathrm{z}}$

\begin{tabular}{|c|c|c|c|c|c|c|c|}
\hline Cultivar & $\mathrm{V}(\%)$ & $\begin{array}{c}\mathrm{A}_{\text {net }} \\
{\left[\mathrm{CO}_{2}\left(\mu \mathrm{mol} \cdot \mathrm{m}^{-2} \cdot \mathrm{s}^{-1}\right)\right]}\end{array}$ & $\begin{array}{c}\mathrm{g}_{\mathrm{s}} \\
{\left[\mathrm{H}_{2} \mathrm{O}\left(\mathrm{mol} \cdot \mathrm{m}^{-2} \cdot \mathrm{s}^{-1}\right)\right]}\end{array}$ & $\begin{array}{c}\mathrm{A}_{\text {nel }} / \mathrm{g}_{\mathrm{s}} \\
{\left[\mathrm{CO}_{2}\left(\mu \mathrm{mol} \cdot \mathrm{mol}^{-1} \mathrm{H}_{2} \mathrm{O}\right)\right]}\end{array}$ & $\begin{array}{c}\mathrm{C}_{\mathrm{i}} \\
\left(\mu \mathrm{mol} \cdot \mathrm{mol}^{-1}\right)\end{array}$ & $\begin{array}{c}\mathrm{E} \\
\left(\mathrm{mmol} \cdot \mathrm{m}^{-2} \cdot \mathrm{s}^{-1}\right)\end{array}$ & 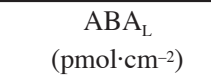 \\
\hline \multicolumn{8}{|c|}{$\begin{array}{cccc}2 & 2 \\
\end{array}$} \\
\hline Autumn Blaze & $>30$ & $20.6 \pm 0.8$ & $0.367 \pm 0.025$ & $56.55 \pm 2.53$ & $228 \pm 4.26$ & $3.64 \pm 0.16$ & $3.27 \pm 0.66$ \\
\hline Autumn Flame & $>30$ & $21.8 \pm 0.6$ & $0.379 \pm 0.021$ & $58.30 \pm 2.21$ & $224 \pm 3.36$ & $3.57 \pm 0.13$ & $4.71 \pm 0.51$ \\
\hline October Glory & $>30$ & $20.2 \pm 1.2$ & $0.344 \pm 0.028$ & $59.36 \pm 1.67$ & $225 \pm 1.58$ & $3.42 \pm 0.19$ & $3.84 \pm 0.73$ \\
\hline Red Sunset & $>30$ & $21.1 \pm 1.4$ & $0.374 \pm 0.038$ & $57.90 \pm 3.26$ & $226 \pm 2.94$ & $3.62 \pm 0.28$ & $2.93 \pm 0.95$ \\
\hline $\begin{array}{l}\text { Summer Red } \\
\text { B. }\end{array}$ & $>30$ & $19.7 \pm 2.8$ & $0.377 \pm 0.014$ & $47.77 \pm 7.05$ & $214 \pm 8.20$ & $3.75 \pm 0.05$ & $3.42 \pm 0.59$ \\
\hline Autumn Blaze & $<10$ & $2.62 \pm 0.66^{\mathrm{AF}}$ & $0.044 \pm 0.011^{\mathrm{RS}}$ & $65.83 \pm 18.98^{\mathrm{AF}, \mathrm{RS}}$ & $235 \pm 29.32^{\mathrm{AF}}$ & $1.06 \pm 0.27$ & $28.13 \pm 2.63^{\mathrm{AF}}$ \\
\hline Autumn Flame & $<10$ & $7.45 \pm 1.34$ All & $0.066 \pm 0.016^{\mathrm{RSSR}}$ & $121.56 \pm 8.98^{\mathrm{AB}, \mathrm{OG}, \mathrm{RS}}$ & $141 \pm 13.42^{\mathrm{AB}}$ & $1.20 \pm 0.20^{\mathrm{RS}, \mathrm{SR}}$ & $20.52 \pm 1.94^{\mathrm{All}}$ \\
\hline October Glory & $<10$ & $3.73 \pm 1.19^{\mathrm{AF}}$ & $0.047 \pm 0.012^{\mathrm{RS}}$ & $85.68 \pm 22.91^{\mathrm{AF}, \mathrm{RS}}$ & $202 \pm 36.36$ & $1.06 \pm 0.24^{\mathrm{RS}}$ & $27.91 \pm 1.67^{\mathrm{RS}, \mathrm{AF}}$ \\
\hline Red Sunset & $<10$ & $2.67 \pm 0.91 \mathrm{AF}$ & $0.025 \pm 0.008^{\mathrm{AF}, \mathrm{OG}}$ & $188.56 \pm 23.50^{\text {All }}$ & $169 \pm 42.34$ & $0.53 \pm 0.16^{\text {All }}$ & $34.07 \pm 2.05^{\mathrm{AF}, \mathrm{OG}}$ \\
\hline $\begin{array}{l}\text { Summer Red } \\
\text { C. }\end{array}$ & $<10$ & $4.03 \pm 1.50^{\mathrm{AF}}$ & $0.036 \pm 0.007 \mathrm{AF}$ & $103.63 \pm 21.38^{\mathrm{RS}}$ & $173 \pm 34.79$ & $0.82 \pm 0.09^{\mathrm{RS}, \mathrm{A}}$ & $30.82 \pm 2.37 \mathrm{AF}$ \\
\hline Autumn Blaze & $<10$ & $1.52 \pm 0.45^{\mathrm{AF}}$ & $0.022 \pm 0.002$ & $78.91 \pm 32.24^{\mathrm{SR}}$ & $219 \pm 47.12^{\mathrm{SR}, \mathrm{AF}, \mathrm{RS}}$ & $0.53 \pm 0.05$ & $31.49 \pm 2.07 \mathrm{SR}$ \\
\hline Autumn Flame & $<10$ & $2.92 \pm 0.70^{\mathrm{AB}, \mathrm{OG}}$ & $0.023 \pm 0.004$ & $130.61 \pm 20.67 \mathrm{SR}, \mathrm{OG}$ & $135 \pm 31.27 \mathrm{AB}$ & $0.54 \pm 0.08$ & $31.16 \pm 2.13^{\mathrm{SR}}$ \\
\hline October Glory & $<10$ & $1.47 \pm 0.58^{\mathrm{AF}}$ & $0.020 \pm 0.004$ & $66.79 \pm 13.58^{\mathrm{SR}, \mathrm{AF}}$ & $233 \pm 20.78^{\mathrm{SR}, \mathrm{RS}}$ & $0.49 \pm 0.10$ & $35.27 \pm 1.43$ \\
\hline Red Sunset & $<10$ & $3.22 \pm 1.32$ & $0.024 \pm 0.009$ & $104.88 \pm 19.52^{\mathrm{SR}}$ & $138 \pm 43.91^{\mathrm{OG}, \mathrm{AB}}$ & $0.57 \pm 0.21$ & $29.08 \pm 3.38^{\mathrm{SR}}$ \\
\hline $\begin{array}{l}\text { Summer Red } \\
\text { D. }\end{array}$ & $<10$ & $2.68 \pm 0.77$ & $0.015 \pm 0.005$ & $256.08 \pm 12.24^{\mathrm{All}}$ & $84 \pm 45.21 \mathrm{AB}, \mathrm{OG}$ & $0.35 \pm 0.13$ & $39.93 \pm 2.9^{\mathrm{AB}, \mathrm{AF}, \mathrm{RS}}$ \\
\hline Autumn Blaze & $>30$ & $13.43 \pm 0.88$ & $0.138 \pm 0.020$ & $101.68 \pm 6.92$ & $165 \pm 10.56$ & $2.33 \pm 0.19$ & $11.73 \pm 1.72$ \\
\hline Autumn Flame & $>30$ & $15.05 \pm 0.79^{\mathrm{RS}, \mathrm{OG}}$ & $0.156 \pm 0.017$ & $99.98 \pm 7.51$ & $164 \pm 11.64$ & $2.53 \pm 0.20$ & $9.3 \pm 1.03^{\mathrm{OG}, \mathrm{RS}}$ \\
\hline October Glory & $>30$ & $12.62 \pm 1.45^{\mathrm{AF}}$ & $0.117 \pm 0.020^{\mathrm{SR}}$ & $115.77 \pm 9.56$ & $143 \pm 12.68^{\mathrm{RS}}$ & $2.24 \pm 0.32$ & $14.28 \pm 2.09 \mathrm{AF}, \mathrm{SR}$ \\
\hline Red Sunset & $>30$ & $11.71 \pm 1.62^{\mathrm{SR}, \mathrm{AF}}$ & $0.126 \pm 0.023$ & $99.32 \pm 7.69$ & $171 \pm 11.67 \mathrm{Rs}$ & $2.06 \pm 0.31$ & $13.41 \pm 2.31 \mathrm{AF}$ \\
\hline Summer Red & $>30$ & $15.35 \pm 1.62^{\mathrm{RS}}$ & $0.173 \pm 0.030^{\mathrm{OG}}$ & $95.50 \pm 9.13$ & $172 \pm 12.86^{\mathrm{OG}}$ & $2.64 \pm 0.32$ & $9.06 \pm 1.94 \mathrm{OG}$ \\
\hline
\end{tabular}

z'Autumn Blaze' = AB, 'Autumn Flame' = AF, 'October Glory' = OG, 'Red Sunset' = RS, 'Summer Red' = SR, and All = different from all other four genotypes. A Fisher's LSD test at $P \leq 0.05$ was performed at each distinct volumetric water content as follows: well-watered and prior to drought (A), initial threshold water deficit (B), $5 \mathrm{~d}$ (continuous) at threshold water deficit (C), and after $4 \mathrm{~d}$ (continuous) of irrigation (D, peak recovery phase). Statistical significance of differences between cultivars are given as $P \leq 0.05$. 
ABA formation and breakdown see Cutler and Krochko, 1999), an understanding of the genetic differences in $\mathrm{ABA}_{\mathrm{L}}$ synthesis, accumulation and catabolism under both irrigated and water stressed conditions may elucidate why transpiration varies among maple genotypes under similar substrate water stress conditions. At the same time, it may allow us to select for drought tolerance, where ABA quantification has already been successfully used as a method to select drought-tolerant Triticum aestivum L. (Innes et al., 1984; Read et al., 1991) and corn (Landi et al., 2001; Pekic et al., 1995; Sanguineti et al., 1996). The agronomic studies, the study by Zhang et al. (2001) that used whole Vicia faba L. plants and found apoplastic ABA accumulation in the stomatal complex to correlate with root sourced water deficit, and our prior work in red maple ecotypes that uncovered higher $\mathrm{ABA}_{\mathrm{L}}$ in wet as opposed to dry site ecotypes (Bauerle et al., 2003a) led us to this hypothesis. Similar in concept to Landi et al. (2001), our approach was to investigate individual leaf $g_{s}$ and $\mathrm{ABA}_{\mathrm{L}}$ with the intention of establishing a selection protocol that would function to predict performance under xeric site conditions. Our results indicate that in the five maple genotypes investigated, $\mathrm{ABA}_{\mathrm{L}}$ becomes elevated as $\mathrm{g}_{\mathrm{s}}$ and substrate moisture content decline. As shown by others (e.g., Trejo et al., 1993), we found that ABA could operate quantitatively to provide dynamic stomatal closure. Thus, our study shows that variation in $\mathrm{ABA}_{\mathrm{L}}$ among the genotypes was quantitatively related to $g_{s}$ at specific substrate water contents. This finding could aid in drought tolerance selection of maple cultivars. Because $\mathrm{ABA}$ is only responsible for signaling stomatal closure, we do not imply that $\mathrm{A}_{\text {net }}, \mathrm{A} / \mathrm{g}_{\mathrm{s}}$, and $\mathrm{C}_{\mathrm{i}}$ can be determined from $\mathrm{ABA}_{\mathrm{L}}$. We do note, however, that the restricted leaf conductance brought about by elevated $\mathrm{ABA}_{\mathrm{L}}$ would likely lower $\mathrm{CO}_{2}$ diffusion into the substomatal cavity, which in turn could lower $A_{\text {net }}$, potentially increase $\mathrm{A} / \mathrm{g}_{\mathrm{s}}$, and lower $\mathrm{C}_{\mathrm{i}}$ values.

Sap flow values were different among two of the genotypes ('Summer Red' and 'October Glory') in response to water stress, but, equipment limitation prevented us from monitoring all five genotypes. Given the equipment limitation, the decision to replicate within a genotype rather than among all five genotypes does indicate that genotype sap flow is different under both well-watered and water stress conditions. More work in the area of both intraspecific and interspecific transpiration variation is still needed in both red maple in specific and woody ornamentals in general.

In conclusion, the results herein support the hypothesis that $\mathrm{ABA}_{\mathrm{L}}$ concentration provides a means of explaining the variation in $\mathrm{g}_{\mathrm{s}}$ among genotypes of maple exposed to similar substrate moisture conditions. Due to reports that ABA in the transpiration stream is not as effective at causing stomatal closure as ABA applied directly to epidermal peels (Wilkinson and Davies, 1997), $\mathrm{ABA}_{\mathrm{L}}$ may be a better indicator of the stomatal response to substrate water deficits than xylem collected ABA because leaf stomata are both the site of ABA action and the link between the plant and the atmosphere. Moreover, the combination of gas exchange, sap flow, and $\mathrm{ABA}_{\mathrm{L}}$ analysis are useful indicators of genotype sensitivity to water deficits. If ELISA sensitivity was increased, assay methodology was made field ready and user friendly, and sample cost was effective, it may be possible to use $\mathrm{ABA}_{\mathrm{L}}$ as a water stress indication tool (if comparative well-watered maximal $g_{s}$ values were know for the species and/or genotype under investigation). However, as previously described, variation among genotype $\mathrm{ABA}_{\mathrm{L}}$ does not appear to carry forward to explaining variation in $\mathrm{A}_{\text {net }}, \mathrm{A} / \mathrm{g}_{\mathrm{s}}$, and $\mathrm{C}_{\mathrm{i}}$. Although this observation seems to limit the usefulness of using $\mathrm{ABA}_{\mathrm{L}}$ as a surrogate for growth or $\mathrm{A}_{\text {net }}$ predictions under water deficits, our study on an ornamental tree species indicates that $\mathrm{ABA}_{\mathrm{L}}$ could become a useful tool in a woody ornamental drought tolerance selection and breeding program. Unlike selection for low $\mathrm{ABA}_{\mathrm{L}}, \mathrm{a} \mathrm{g}_{\mathrm{s}}$ surrogate that indicates the potential for $\mathrm{CO}_{2}$ diffusion and $\mathrm{A}_{\text {net }}$, in agronomic crops that are frequently irrigated, the next step in woody ornamental research should focus on recommendations for cultivar selection based on site specific unirrigated moisture characteristics.

\section{Literature Cited}

Alves, A.C. and T.L. Setter. 2000. Response of cassava to water deficit: Leaf area growth and abscisic acid. Crop Sci. 40(1):131-137.

Bauerle, W.L., J.B. Dudley, and L.W. Grimes. 2003b. Genotypic variability in photosynthesis, water use, and light absorption among red and freeman maple cultivars in response to drought stress. J. Amer. Soc. Hort. Sci. 128:337-342.

Bauerle, W.L., T.M. Hinckley, J. Cermak, J. Kucera, and K. Bible. 1999. The canopy water relations of old growth douglas-fir trees. Trees 13:211-217.

Bauerle, W.L., C.J. Post, M.F. McLeod, J.B. Dudley, and J.E. Toler. 2002. Measurement and modeling of the transpiration of a temperate red maple container nursery. Agr. For. Meteorol. 114:45-57.

Bauerle, W.L., J.E. Toler, and G.G. Wang. 2004b. The stomatal conductance of Acer rubrum L. ecotypes under varying soil and atmospheric water conditions: Predicting stomatal responses with an abscisic acidbased model. Tree Physiol. 24:805-811.

Bauerle, W.L., T.H. Whitlow, T.L. Setter, T.L. Bauerle, and F.M. Vermeylen. 2003a. Ecophysiology of Acer rubrum L. seedlings from contrasting hydrologic habitats: Growth, gas exchange, tissue water relations, abscisic acid, and carbon isotope discrimination. Tree Physiol. 23:841-850.

Bauerle, W.L., T.H. Whitlow, T.L. Setter, and F.M. Vermeylen. 2004a. Abscisic acid synthesis in Acer rubrum L. leaves-A vapor pressure deficit mediated response. J. Amer. Soc. Hort. Sci. 129:182-187.

Borel, C., T. Simonneau, D. This, and F. Tardieu. 1997. Stomatal conductance and ABA concentration in the xylem sap of barley lines of contrasting genetic origins. Austral. J. Plant Physiol. 24:607-615.

Cutler, A.J. and J.E. Krochko 1999. Formation and breakdown of ABA. Trends Plant Sci. 4:472-478.

Davies, W.J. and J. Zhang. 1991. Root signals and the regulation of growth and development of plants in drying soil. Annu. Rev. Plant Physiol. Plant Mol. Biol. 42:55-76.

Freundl, E., E. Steudle, and W. Hartung. 1998. Water uptake by roots of maize and sunflower affects the radial transport of abscisic acid and its concentration in the xylem. Planta 207:8-19.

Fulton A., R. Bucher, B. Olson, L. Schwankl, C. Gilles, N. Bertagna, J. Walton, and K. Shackel. 2001. Rapid equilibration of leaf and stem water potential under field conditions in almonds, walnuts, and prunes. HortTechnology 11:609-615.

Gutiérrez, M.V., R.A. Harrington, F.C. Meinzer, and J.H. Fownes. 1994. The effect of environmentally induced stem temperature gradients on transpiration estimates from the heat balance method in two tropical woody species. Tree Physiol. 14:179-190.

Innes, P., R.D. Blackwell, and S.A.Quarrie. 1984. Some effects of genetic variation in drought-induced abscisic acid accumulation on the yield and water use of spring wheat. J. Agr. Sci. 102:341-351.

Jackson, M. 1993. Are plant hormones involved in root to shoot communication? Adv. Bot. Res. 19:103-187.

Kozlowski, T.T. and S.G. Pallardy. 1997. Physiology of woody plants. 2nd ed. Academic, San Diego.

Landi, P., M.C. Sanguineti, S. Conti, and R. Tuberosa. 2001. Direct and correlated responses to divergent selection for leaf abscisic acid concentration in two maize populations. Crop Sci. 41:335-344.

Pekic, S., R. Stikic, V. Tomljanovic, M. Andjekovic, M. Ivanovic, and 
S.A. Quarrie. 1995. Characterization of maize lines differing in leaf abscisic acid content in the field: Abscisic acid physiology. Ann. Bot. 75:67-73.

Quarrie, S.A. 1991. Implications of genetic differences in ABA accumulation for crop production, p. 227-243. In: W.J. Davies and H.G. Jones (eds.). Abscisic acid: Physiology and biochemistry. Bios Scientific Publishers, Oxford, U.K.

Read, J.J., R.C. Johnson, B.F. Carver, and S.A. Quarrie. 1991. Carbon isotope discrimination, gas exchange, and yield of spring wheat selected for abscisic acid content. Crop Sci. 31:139-146.

Sanguineti, M.C., S. Conti, P. Landi, and R. Tuberosa. 1996. Abscisic acid concentration in maize leaves: Genetic control and response to divergent selection in two populations. Maydica 41:193-203.

Shackel, K., A. Fulton, R. Buchner, B. Olsen, L. Schwankl, C. Gilles, N. Bertagna, and J. Walton. 2001. Rapid equilibration of leaf and stem water potential under field conditions. HortScience 36:430.

Steinberg, S.L., C. Van Bavel, and M.J. McFarland. 1990. Improved sap flow gauge for woody and herbaceous plants. Agron. J. 82:851-854.

Tardieu, F., J. Zhang, N. Katerji, O. Bethenod, S. Palmer, and W.J.
Davies. 1992. Xylem ABA controls the stomatal conductance of fieldgrown maize subjected to soil compaction or soil drying. Plant Cell Environ. 15:185-191.

Trejo, C.L., W.J. Davies, and L.D. Ruiz. 1993. Sensitivity of stomata to abscisic acid. Plant Physiol. 102:497-502.

Whitehead, D. 1998. Regulation of stomatal conductance and transpiration in forest canopies. Tree Physiol. 18:633-644.

Wilkinson, S. and W.J. Davies. 1997. Xylem sap pH increase: A drought signal received at the apoplastic face of the guard cell that involves the suppression of saturable abscisic acid uptake by the epidermal symplast. Plant Physiol. 113:559-573.

Wilkinson, S. and W.J. Davies. 2002. ABA-based chemical signalling: The co-ordination of responses to stress in plants. Plant Cell Environ. 25:195-210.

Zeevaart, J.A.D. and R.A.Creelman. 1988. Metabolism and physiology of abscisic acid. Ann. Rev. Plant Physiol. Plant Mol. Biol. 39:439-473.

Zhang, S.Q., W.H. Outlaw, and K. Aghoram. 2001. Relationship between changes in the guard cell abscisic-acid content and other stress-related physiological parameters in intact plants. J. Expt. Bot. 52:301-308. 